\title{
THE INFLUENCE OF ETHNOMATHEMATICS-CONTAINED PROBLEM BASED LEARNING MODEL AND MATHEMATICAL DISPOSITION SKILL TOWARD MATHEMATICAL REPRESENTATION
}

\author{
Sofri Amalia R. \\ Mathematics Department Peradaban University \\ sofri.rizkia@gmail.com
}

\begin{abstract}
This research aims to: (1) knowing the positive influence of ethnomathematics-contained PBL model towards mathematical representation skill, (2) knowing the positive influence of mathematical disposition towards mathematical representation skill, and (3) knowing the positive influence of ethnomathematics-contained PBL model and mathematical disposition skill towards mathematical representation. This is a quantitative research. Four classes in fifth semester from Educational of Elementary School students of 2016/2017 became the population of this research. The sample in this research was Education of Elementary School 2 (two) as the experiment class, and class of Educational of Elementary School 1 (one) as the control class. As for data collection, the used of documentation, test, questionnaire, and observation technique was done to complete this research. The research analysis data was using SPSS 16, which is homogeneity test, normality test, simple regression test, and double regression test. The result showed that (1) there is positive influence of ethnomathematics-contained Problem Based Learning (PBI) model and mathematical disposition skill toward mathematical representation, (2) there is positive influence of mathematical disposition towards mathematical representation skill, (3) there is positive influence of Problem Based Learning (PBL) model and mathematical disposition skill toward mathematical representation.
\end{abstract}

Keywords: ethnomathematics-contained PBL, Mathematical Disposition, and Mathematical Representation.

\section{INTRODUCTION}

According to Rachmayani (2014, p. 14), mathematic is basic knowledge, either the applied aspect or the reasoning aspect, it has essential role in the effort of knowledge and technology mastery. That is how important mathematic is, hence, mathematic is learned in every level of schools in Indonesia, from elementary students until college. Ruseffendi (as cited in Susanto, 2013) states, mathematic is important as the helper, knowledge, mindset advisor, also attitude former. There are so many benefits of mathematic, yet it is the most hated subject by students, because they think mathematic is difficult.

Hudiono (2005, p. 19) proposes that representation skill supports students in understanding the concept of mathematic being learned and its relation. Besides, it also 
communicates ideas of mathematic, knows the connection between the concepts of mathematic and applies mathematic into realistic mathematic problems through modeling. In learning activities, mathematic representation is one of the standards that must be achieved by students.

Based on the interview with the lecturer in Teacher Training and Education Faculty of Peradaban Bumiayu University, the mathematic representation is still low. Students are still unable to express their ideas into mathematic model to plan a settling. Below is the investigation from fifth semester students of Education of Elementary School of Peradaban Bumiayu University.

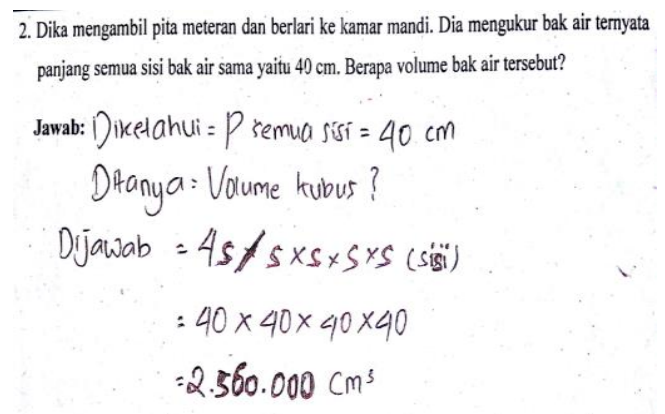

\section{Picture 1. The Result of Investigation Question}

It showed from the Picture 1 that students could not draw picture similar with cube. One of the students is changing the problem into mathematic mode or formula to solve it. It shows that the students are not master yet in visual representation, equation, and written text. The lack of students' representation skill caused by the learning model used by the lecturer is not appropriate enough. The lecturer is still the central of the learning activities. The learning delivering by lecturer is still stuck on to the textbook. The way of teaching is still used to material delivery, giving questions, and asking the students to do the practice. Therefore, it is impossible to grow or improve the representation skill optimally.

According to Priyono and Hermanto (2015, p. 58), mathematical representation skill will ease the students in doing problem solving. Let alone it will be good if it is also supported by high motivation to learn. Therefore, if students faced difficulty, they will not give up so easily and try harder to solve the problems. Hutagaol (2013) stated that problem faced by students in mathematic learning is lack of expanding representative skill. It is because of the teacher that did not give the opportunities to the student to present their self-representative, yet they should present what they already get from the teachers. Therefore, teachers need to make good lesson plan which suitable with their students' 
need. One of the models that might help face those problems is problem-based learning (PBL) models. Based on Tan (2003), PBL is learning approach that makes confrontation to the student with practice problems or learning activity that begin with problems and have a context with real life.

Dewanto (2007) suggests, basically, problem given in PBL in a word problem form, it should be interested and represented in a form of mathematic. The process of interpretation and representation become essential due to the connection between mathematic ideas related to the mathematic representative that should be given to the student. There are some phases in applying PBL, which are problem oriented, organized student to learn, guiding individual or group experience, developing and presenting result work, and analyzing and evaluating the process of problem solving. PBL models are usually combined with ethnomathematics.

According to Begg and Hamilton (2001, p. 1), ethnomathematics refers to culture of mathematic. It is not only referring to ethnic culture but also to the general experience likewise language, religion, customs, or history. From that statement above, we know that activity in PBL refers to activity that has an abstraction process from real life experience in daily life toward mathematic and vice versa. It involves grouping activity, calculating, measuring, designing building or tools, make pattern, counting, determining location, playing, explaining, and so on (Rachmawati, 2012, p. 4). Hence, ethnomathematics is specific ways used by particular culture group or community in mathematic activities.

A problem given in PBL models is problems that consist of ethnomathematics. One of the examples is as the following; 2Tang tea is one of the teas that have Tegal characteristic. It has some variant. Interview is prepared to 100 women in Tegal. The result of the interview said that 44 women like premium 2Tang, 25 like super 2Tang, 20 Jasmine tea, and 11 like green tea. Make circle diagram! Moreover, specify the biggest and the lowest percentage of tea.

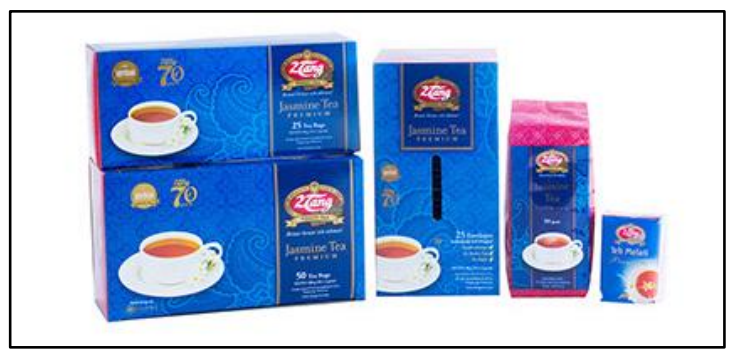

Picture 2. 2Tang tea 
Another factor that is influence mathematic representative ability is mathematical disposition. Based on NCTM (as cited in Mahmudi, 2010), mathematical disposition which cover several components as the following;

1) Self-confident in using mathematic to face the problems

2) Thinking flexible in exploring mathematic ideas, persistent in doing mathematic task

3) Interested, having high curiosity

4) Monitoring and reflecting thinking and performance

5) Appreciate mathematic application in disciplines or in daily life

6) Appreciating mathematic role as tools and as a language.

The idea is in line with Bondan and Sofuroh (2014), productive disposition related with the tendency to do productive habit, to see mathematic as something make sense, useful, meaningful and valuable, also have self-confident and perseverance in studying/working with mathematic. PBL models contain ethno mathematic expected to develop students' mindset. Students can have a control over in visual representative, equation and written text with given problems related with culture activity (ethnomathematics). With mathematical disposition ability, learning activity could be more meaningful and student could develop their ability.

Based on the rational above, the researcher indicated some problems, which were: 1) lack of mathematic representation ability, 2) lack of mathematical disposition ability, 3) infeasible learning model, 4) passive students in the learning process. Therefore, the researcher organized some research problems, which were: (1) Is there any positive effect of ethnomathematics-contained PBL model toward mathematical representation ability? (2) Is there any positive effect of mathematical disposition towards mathematic representation?, (3) is there any positive effect of ethnomathematics-contained PBL model and mathematical disposition ability towards mathematic representation ability?

The aims of the study were: (1) investigate the positive effect of ethnomathematics-contained PBL model toward mathematical representation ability, (2) investigate the positive effect of mathematical disposition ability towards mathematic representation ability, (3) investigate the positive effect of ethnomathematics-contained PBL model, and mathematical disposition ability towards mathematic representation ability. 


\section{RESEARCH METHODS}

This study was conducted in University of Peradaban Bumiayu, academic year 2016/2017. In this case, the researcher used experimental quantitative research design. Moreover, the researcher applied posttest control design approach in the study. The population of the study was students from four classes in fifth semester of Educational of Elementary School, academic year 2016/2017. The population sample was the Educational of Elementary School 2 as the experimental class and Educational of Elementary School 1 as the controlled class.

The data collection methods were documentation, test, questionnaire, and observation. The questions have been tested before distributed to the students. The researcher analyzed the data with SPSS 16 that contained homogeneity test, normality test, simple regression test, and multiple regression tests.

\section{FINDINGS AND DISCUSSION}

Before gave the posttest to the students, the researcher conducted trials of the questions and she obtained 5 valid questions, which were reliable questions, medium difficulty level, easy and hard, the strength questions differentiator based on good and very good criteria.

The next step was the implementation of pre-recruitment test, which were normality test and homogeneity test of preliminary data and the final data. The result of the test was the representation of the two experimental classes' data and control normal distributed and has the same variant (homogenous). After the pre-recruitment test, the researcher analyzed the data with SPSS 16. The result of SPSS 16 test would be explained as follows.

\section{The effect of ethnomathematics-contained PBL $\left(X_{1}\right)$ towards mathematic representation ability $(Y)$.}

Hypothesis:

$H_{0}: \beta_{1}=0$ (There is no linear effect of ethnomathematics-contained PBL model towards students' representation ability)

$H_{1}: \beta_{1} \neq 0$ (There is a linear effect of ethnomathematics-contained PBL model towards students' representation ability) 
In this study, the calculation used SPSS program. The result would be presented in Table 1.

Tabel 1. Output Anova Regresi $X_{1}$ Terhadap $Y$

\begin{tabular}{lrrrrr}
\hline \multicolumn{1}{c}{ Model } & Sum of Squares & df & Mean Square & F & Sig. \\
\hline $\begin{array}{l}1 \text { Regressio } \\
\mathrm{n}\end{array}$ & 1644.793 & 1 & 1644.739 & 182.232 & $.000^{\mathrm{a}}$ \\
$\mathrm{R}$ & & & & & \\
Total & 342.982 & 38 & 9.026 & & \\
\hline a. Predictors: (Constant), PBL_etno & & & & \\
b. Dependent Variable: Representasi_mat & & &
\end{tabular}

Table 1 showed $F$ value $=F=182,232$ and sig value $0000=0 \%<5 \%$ that meant $H_{0}$ was rejected. It indicated that there is a significant linear effect of ethnomathematics-contained PBL model towards the students' representation ability. The regression coefficient would be presented in Table 2 .

Tabel 2. Output Coefficients

\begin{tabular}{|c|c|c|c|c|c|c|c|}
\hline & \multirow{2}{*}{ Model } & \multicolumn{2}{|c|}{ Unstandardized Coefficients } & \multicolumn{2}{|c|}{ Standardized Coefficients } & \multirow[b]{2}{*}{$\mathrm{t}$} & \multirow[b]{2}{*}{ Sig. } \\
\hline & & B & Std. Error & Beta & & & \\
\hline \multirow[t]{2}{*}{1} & (Constant) & -27.408 & 8.206 & & & -3.340 & .002 \\
\hline & PBL_etno & 1.381 & .102 & & .910 & & .000 \\
\hline
\end{tabular}

a. Dependent Variable: Representasi_mat

Table 2 showed that $a=-27.408, b=1.381$ that indicated regression equation on $\hat{Y}=-27.408+1.381 X_{1}$. The result meant that in every additional variable of one unit of ethnomathematics-contained PBL model $\left(X_{1}\right)$ increased 1.381 of the mathematical representation ability value $(Y)$. There was the sign of positive regression coefficient that showed ethnomathematics-contained PBL model has positive effect towards the mathematical representation ability. The effect value would be presented in Table 3.

Tabel 3. Output Model Summary $X_{1}$ Towads $Y$

\begin{tabular}{lrrr}
\hline Model & $\mathrm{R} \quad$ R Square & Adjusted R Square & Std. Error of the Estimate \\
\hline $1 \quad .910^{\mathrm{a}}$ & .827 & .823 & 3.00430 \\
\hline
\end{tabular}

Based on table 3, it is obtained that R square score in the amount of $0,827=82,7 \%$. That score showed that variable of PBL model which ethnomathematics-contained was influenced the mathematical representation ability in the amount of $82,7 \%$ or the $27,3 \%$ was influenced by another factor. 


\section{The Influence of Mathematical Disposition Test $\left(x_{2}\right)$ Towards The ability of Mathematical Representation ( $Y$ )}

The hypothesis that used is:

$H_{0}: \beta_{2}=0$ (There is no linear influence of mathematical disposition ability towards the ability of students mathematical representation)

$H_{1}: \beta_{2} \neq 0$ (there is linear influence of mathematical disposition ability towards the ability of students mathematical representation)

The result can be seen in the Table 4 .

Table 4. Output Anova of Regression $X_{2}$ Towards $Y$

\begin{tabular}{ccccccc}
\hline & Model & Sum of Squares & df & Mean Square & F & Sig. \\
\hline \multirow{4}{*}{1} & Regression & 1586.982 & 1 & 1586.98 & 150.465 & $.000^{\mathrm{a}}$ \\
& Residual & 400.793 & 38 & 10.547 & & \\
\multicolumn{2}{l}{ a. Predictors: (Constant), disposisi_mat, b. Dependent Variable: representasi_mat }
\end{tabular}

Table 4. above obtained that $F=150.465$ score and the significance score is $0,000=0 \%<5 \%$ which means that $H_{0}$ rejected. It means that there was a linear influence of mathematical disposition ability towards the ability of students' mathematical representation. The regression coefficient seen in the Table 5.

Table 5. Output Coefficients of regression equation $X_{2}$ Towards $Y$

\begin{tabular}{|c|c|c|c|c|c|c|}
\hline & \multirow{2}{*}{ Model } & \multicolumn{2}{|c|}{$\begin{array}{l}\text { Unstandardized } \\
\text { Coefficients }\end{array}$} & \multirow{2}{*}{$\begin{array}{c}\begin{array}{c}\text { Standardized } \\
\text { Coefficients }\end{array} \\
\text { Beta }\end{array}$} & \multirow[b]{2}{*}{$\mathrm{t}$} & \multirow[b]{2}{*}{ Sig. } \\
\hline & & B & Std. Error & & & \\
\hline \multirow[t]{2}{*}{1} & (Constant) & -108.339 & 15.621 & & -6.935 & .000 \\
\hline & disposisi_mat & 1.342 & .109 & & .89412 .266 & .000 \\
\hline
\end{tabular}

Based on Table 5, it is known that the score of $a=-108.339, b=1.342$ so it was obtained that the regression equation $\widehat{Y}=-108.339+1.342 X_{2}$. It is seen that the sign of positive regression coefficient, so, the ability of mathematical disposition have a positive influence towards the ability of mathematical representation.

Table 6. Output Model Summary $X_{2}$ Towards $Y$

\begin{tabular}{|c|c|c|c|c|}
\hline Model & $\mathrm{R}$ & $\begin{array}{c}\mathrm{R} \\
\text { Square }\end{array}$ & Adjusted R Square & $\begin{array}{l}\text { Std. Error of the } \\
\text { Estimate }\end{array}$ \\
\hline 1 & $.894^{\mathrm{a}}$ & .798 & .793 & 3.24764 \\
\hline
\end{tabular}


Based on table 6 , it is obtained that the $\mathrm{R}$ square score in the amount of $0,798=$ $79.8 \%$. That score showed that the variable of mathematical disposition ability influenced the mathematical representation ability in the amount of $79.8 \%$ or the $20,2 \%$ was influennced by another factor.

\section{The Influence of Ethnomathematics-contained PBL Model $\left(X_{1}\right)$, and the Ability of} Mathematical Disposition $\left(X_{2}\right)$ Towards the Ability of Mathematical Representation $(Y)$.

Hypothesis formulation:

$H_{0}: \beta=0$ (there is no linier influence of PBL model which contains ethnomathematic and the ability of mathematics disposition towards the ability of students mathematical representation)

$H_{1}: \beta \neq 0$ (there is linier influence of PBL model which contains ethnomathematic and the ability of mathematics disposition towards the ability of students mathematical representation)

The result can be seen in Table 7 .

Table 7. Output Anova of Regression $X_{1}$ and $X_{2}$ Towards $Y$

\begin{tabular}{lrrccc}
\hline & \multicolumn{1}{c}{ Sum of } & \multicolumn{2}{c}{ Mean } & \\
Model & Squares & df & Square & F & Sig. \\
\hline 1 Regression & 1752.723 & 2 & 876.362 & 137.950 & $.000 \mathrm{a}$ \\
Residual & 235.052 & 37 & 6.353 & & \\
Total & 1987.775 & 39 & & & \\
\hline
\end{tabular}

a. Predictors: (Constant), PBL_etno, disposisi_mat

b. Dependent Variable: representasi_mat

Based on table 7 , it is obtained that $F=137.950$ score and the significance score was $0,000=0 \%<5 \%$. It can be concluded that there is linier influence of ethnomathematic -contained PBL model and the ability of mathematical disposition towards the ability of mathematical representation. 
The regression coefficient seen in the Table 8 .

Table 8. Output Coefficients of Regression equation $X_{1}$ and $X_{2}$ Towards $Y$

\begin{tabular}{|c|c|c|c|c|c|}
\hline \multirow[b]{2}{*}{ Model } & \multicolumn{2}{|c|}{$\begin{array}{l}\text { Unstandardized } \\
\text { Coefficients }\end{array}$} & \multirow{2}{*}{$\begin{array}{c}\begin{array}{c}\text { Standardized } \\
\text { Coefficients }\end{array} \\
\text { Beta }\end{array}$} & \multirow[b]{2}{*}{$\mathrm{t}$} & \multirow[b]{2}{*}{ Sig. } \\
\hline & B & Std. Error & & & \\
\hline 1 (Constant) & $\begin{array}{r}- \\
76.08 \\
5\end{array}$ & 13.670 & & -5.566 & .000 \\
\hline Disposisi_mat & .656 & .159 & .436 & 4.122 & .000 \\
\hline PBL_mat & .821 & .161 & .541 & 5.108 & .000 \\
\hline
\end{tabular}

a. Dependent Variable: representasi_mat

In Table 8 seen that the scores are $a=-76.085, b=0.656$, and $c=0.821$. The regression in the form of $\hat{Y}=-76.085+0.656 X_{1}+0.821 X_{2}$. It seen that the coefficient sign of regression is positive, which means that ethnomathematicscontained PBL model and the ability of mathematical disposition is positively influence the ability of mathematical representation. The influence magnitude was shown in Table 9.

Table 9. Output Model Summary $X_{1}$ dan $X_{2}$ Towards $Y$

\begin{tabular}{ccccc}
\hline Model & $\mathrm{R}$ & $\mathrm{R}$ Square & Adjusted R Square & $\begin{array}{c}\text { Std. Error of the } \\
\text { Estimate }\end{array}$ \\
\hline 1 & $.939^{\mathrm{a}}$ & .882 & .875 & 2.52047 \\
\hline \multicolumn{2}{l}{ a. Predictors: (Constant), PBL etno, disposisi_mat }
\end{tabular}

a. Predictors: (Constant), PBL_etno, disposisi_mat

From Table 9, it obtained that $\mathrm{R}$ square $\mathrm{Score}=0,882=82,2 \%$. That score showed that variable of ethnomathematics-contained PBL model and the ability of mathematics disposition together influence the ability of mathematical representation in the amount of $88,2 \%$ and there is $11,8 \%$ which influenced by another factor.

\section{CONCLUSION}

Based on the analysis scores and the discussion in the previous chapter, accordingly, the conclusion of this development study will be explained as follow:

1. There is positive influence of ethnomathematics-contained Problem Based Learning (PBL) model and the ability of mathematical disposition towards the ability of 
mathematical representation.

2. There is positive ability of mathematical disposition towards the ability of mathematical representation.

3. There is positive influence of Problem Based Learning (PBL) and the ability of mathematical disposition towards the ability of mathematical representation.

\section{REFERENCES}

Begg, A \& Hamilton. 2001. Ethnomathematics: Why, and What Else?. ZDM . 33(3): 7174.

Dewanto, D. (2007). Improving Multiple Mathematical Representation Ability of Students through Problem Based Learning. Disertas. PPs UPI: Unpublished.

Hudiono. 2005. Improving Representation and Problem Solving Ability of High School Students Through Mathematics Project Learning Model. Essay. FPMIPA UPI Bandung: Unpublished.

Hutagaol, K. 2013. Contextual learning to improve Mathematical Representation of Junior High School students. Jurnal Ilmiah Mathematics Study Program STKIP Siliwangi Bandung, 2 (1): 91.

Mahmudi, A. (2010). Review of the Association between Mathematical Problem Solving and Mathematical Disposition. Yogyakarta: FMIPA Yogyakarta State University.

Priyono, S., dan Hermanto, R. 2015. Improving Ability of Mathematical Representation of Learners Using Problem Based Learning Model (PBL) with Media Software. Journal of Research on Education and Teaching of Mathematics, 1 (1): 55-64.

Rachmawati, I. 2012. Exploration of Ethnomatics Society of Sidoarjo. Essay. Surabaya State University.

Rachmayani, D. 2014. “Application of Reciprocal Teaching Learning to Improve Mathematical Communication Skill and Student Learning Mathematics Independence". Journal of Education UNSIKA, 2(1): 2338-2996.

Sofuroh. 2014. Model Learning Cycle 5E Dengan Pendekatan Scientific Untuk Meningkatkan Disposisi Matematis dan Berpikir Kritis. Unnes Journal of Mathematics Education Research, 3 (2), 91-97.

Susanto, A. 2013. Learning Theory And Learning In Primary School. Jakarta: Kencana Prenada Media Group.

Tan, O.S. 2003. Problem Based Learning Innovation: Using Problem to Power Learning in 21st Century. Singapore: Thompson Learning. 